\title{
Diskriminasi pada Pemain Game Online Perempuan
}

\section{Woman Game Online Player Discrimination}

\author{
Brigietta Irna Pramesty \\ Universitas Atma Jaya Yogyakarta \\ J1 Babarsari 44 Yogyakarta 55281, Indonesia \\ Email: brigiettairna@gmail.com
}

Received : January 1, 2021 ; Revised: June 10, 2021; Accepted: August 15, 2021

\begin{abstract}
Advances in technology have also developed entertainment facilities that are served to the community. One of the available entertainment facilities is mobile games or mobile games. Mobile games have considerable appeal for people of all ages and genders. This study analyzes the discrimination of female "Mobile Legends: Bang Bang" game players in the interaction of online game players Mobile Legend: Bang Bang. Research on gender discrimination focuses more on issues of work and gender roles in the cultural structure of society but still rarely researches leisure activities. For this reason, the study aims to determine the discrimination experienced by female players in Mobile Legends: Bang Bang and the forms of verbal discrimination spoken by the players during the game. This research was conducted using the phenomenological method to explore the experiences of the female players. The adventures of female players are used to understand the phenomena that lead to discrimination. The results of this study show that female players have experienced discrimination from male players. Discriminatory words and sentences indirectly degrade the degree and dignity of female players because they accuse female players of being prostitutes, being equated with animals, and mentioning that the Mobile Legend game is not a place for women. This research shows that gender discrimination occurs in the employment sector and in the entertainment sector, one of which is online games.
\end{abstract}

Keywords: discrimination; interactive games; mobile games; Mobile Legends; woman players.

\begin{abstract}
Abstrak
Kemajuan teknologi turut mengembangkan sarana hiburan yang disuguhkan untuk masyarakat. Salah satu sarana hiburan yang tersedia adalah permainan seluler atau mobile games. Mobile games memiliki daya tarik yang cukup besar bagi masyarakat dari berbagai kalangan usia maupun gender. Penelitian ini menganalisis diskriminasi pada pemain game "Mobile Legends: Bang Bang" perempuan pada interaksi pemain game online Mobile Legend:Bang Bang. Penelitian tentang diskriminasi gender lebih banyak berpusat pada persoalan pekerjaan dan peran gender dalam struktur budaya masyarakat, tetapi masih jarang meneliti pada kegiatan hiburan (leisure). Untuk itu, penelitian
\end{abstract}


bertujuan untuk mengetahui diskriminasi yang dialami oleh pemain perempuan Mobile Legends: Bang Bang dan bentuk-bentuk diskriminasi verbal yang diucapkan oleh para pemain selama permainan berlangsung. Penelitian ini dilakukan dengan menggunakan metode fenomenologi untuk menggali pengalaman dari para pemain perempuan. Pengalaman dari pemain perempuan digunakan untuk memahami fenomena yang mengarah pada diskriminasi. Hasil penelitian ini memperlihatkan bahwa pemain perempuan pernah mengalami diskriminasi dari pemain laki-laki. Kata-kata dan kalimat diskriminatif dikemukakan dengam menyebut pemain perempuan sebagai pelacur, disamakan dengan binatang, dan menyebutkan bahwa permainan Mobile Legend bukan tempat bagi perempuan. Melalui penelitian ini, menunjukkan bahwa diskriminasi gender terjadi tidak hanya pada sektor pekerjaan, tetapi juga pada sektor hiburan, salah satunya pada permainan daring.

Kata Kunci: diskriminasi; Mobile Legends; permainan interaktif; pemain perempuan.

\section{Pendahuluan}

Kemajuan teknologi mempengaruhi perkembangan sarana hiburan untuk masyarakat. Salah satu sarana hiburan yang tersedia adalah game atau permainan. Game atau permainan di era digital ini dapat diakses menggunakan telepon selular atau smartphone dan dikenal dengan istilah permainan seluler atau mobile games.

Mobile games memiliki daya tarik yang cukup besar bagi masyarakat dari berbagai kalangan usia maupun gender (laki-laki dan perempuan). Hal ini dapat dibuktikan dengan hasil studi terkait game pada tahun 2020 yang dilakukan oleh We Are Social dan Hootsuite dan diunggah dalam laman website DataReportal (Kemp, 2020) dari 3.5 miliar orang yang bermain game atau gamer, $80 \%$ di antaranya bermain mobile games. Kepopuleran mobile games berbasis gender di Indonesia juga memiliki hasil sebanyak $49 \%$ pengguna laki-laki dan $51 \%$ pengguna perempuan (Maulida, 2018).
Mobile games dapat dikatakan sebagai permainan interaktif. Permainan interaktif merupakan kegiatan kreatif yang mengembangkan kreasi untuk diproduksi dan didistribusikan menjadi sebuah permainan komputer dan video yang bersifat hiburan, ketangkasan, dan edukasi (Latief, 2017: 13). Mobile games dapat dikatakan sebagai permainan interaktif karena selain memberikan hiburan dapat memberikan pelajaran dan mengasah ketangkasan para pemain dengan melibatkan proses berpikir dan berinteraksi antara para pemain untuk menyusun sebuah strategi dengan pemain lainnya lalu berkoordinasi menggunakan fitur yang terdapat dalam game. Fitur yang digunakan untuk berinteraksi dalam sebuah game yaitu fitur chat dan voice chat. Fitur tersebut dapat digunakan untuk memberi pesan singkat menggunakan tulisan atau suara seperti orang yang sedang bertelepon. Para pemain dapat menggunakan chat dan voice chat untuk berkomunikasi dengan pemain lainnya untuk membahas mengenai 
strategi yang akan digunakan, memberi saran kepada pemain lain, dan bisa sekedar bertegur sapa dengan sesama pemain.

Para pemain mobile games sebagian besar jarang menggunakan nama dan foto asli mereka karena para pemain game atau gamer memiliki kebebasan untuk menunjukkan atau menyembunyikan gender mereka (laki-laki dan perempuan) dalam profil akun game (Usmanda, 2019). Namun tak jarang identitas mereka terbongkar karena menggunakan fitur voice chat (terdengar suara laki-laki atau perempuan), tidak sengaja menggunakan foto asli akun media sosial yang tersambung ke dalam games tersebut, atau menggunakan nama asli mereka untuk ID name.

Sebagian orang mungkin tidak masalah apabila identitasnya terbongkar, tetapi ada pula yang merasa cemas karena takut diperlakukan dengan tidak baik oleh pemain lain. Perlakuan tidak baik tersebut didapatkan oleh pemain saat tim mereka kalah dan juga memang mereka berniat mengejek atau menghina pemain lain yang dapat memicu diskriminasi antarpemain. Diskriminasi adalah sebuah prasangka atau perilaku yang membedakan seseorang karena orang tersebut berasal dari identitas sosial tertentu seperti agama, etnis, ras, gender, dan orientasi seksual (Denny, 2014).

Diskriminasi bisa terjadi kepada siapa saja dan kerap kali terjadi pada pemain saat mereka bermain game namun tidak jarang pemain perempuan menjadi korban diskriminasi saat bermain game. Saat identitas mereka diketahui sebagai perempuan, mereka dianggap lemah dan tidak pandai bermain mobile games tersebut oleh rekan pemain lainnya. Diskriminasi terjadi pada pemain perempuan saat mereka mendapat pesan atau komentar negatif dari rekan pemain lain melalui fitur chat atau voice chat yang tersedia dalam game (Saputra, 2019).

Penelitian ini menganalisis diskriminasi pemain game online perempuan yang bermnain game Mobile Legends: Bang Bang. Penelitian sebelumnya tentang diskriminasi gender dilakukan oleh Tahar (2012) yang membahas tentang diskriminasi di sektor pekerjaan. Penelitian lain, dari Murnalungito (2016) membahas tentang diskriminasi pada perempuan yang mengalami kehamilan tidak direncanakan (KTD). Pada dua penelitian ini, membahas diskriminasi gender yang dialami pada sektor pendidikan dan pekerjaan, sedangkan penelitian yang membahas tentang diskriminasi gender pada sektor kegiatan hiburan seperti bermain games masih jarang dilakukan. Untuk itu, penelitian ini akan mengisi gap tersebut dengan menggali pengalaman pemain perempuan saat mereka bermain game dan melakukan interaksi dengan pemain lain menggunakan fitur chat atau voice chat yang ada di dalam games untuk melihat bentukbentuk diskriminasi yang diterima. Peneliti memilih pemain perempuan dalam penelitian karena berdasarkan data penelitian (Maulida, 2018) pengguna perempuan yang bermain game di Indonesia lebih banyak daripada pemgguna laki-laki yaitu sebanyak $51 \%$ pengguna perempuan. 
Game online yang Peneliti pilih yaitu game Mobile Legends: Bang Bang (MLBB) karena MLBB berada di peringkat kedua dalam top grossing dan peringkat pertama top free di Play Store yang diunggah sebanyak $100 \mathrm{M}+$ dengan review 4.2 bintang.

Penelitian ini berfokus pada diskriminasi pada pemain perempuan game Mobile Legends: Bang Bang. Diskriminasi yang diteliti berasal dari pengalaman pemain Mobile Legends: Bang Bang perempuan saat bermain game Mobile Legends: Bang Bang. Pengalaman diskriminasi tersebut berupa kata dan kalimat dalam penggunaan bahasa sebagai sarana komunikasi yang membedakan dan menyudutkan seseorang karena orang tersebut berasal dari identitas sosial tertentu seperti agama, ras, gender, kelas sosial, dan orientasi seksual.

\section{Kerangka Teori}

Penelitian ini didasari oleh teori yang telah Peneliti pilih untuk membantu analisis hasil penelitian. Teori yang telah dipilih yaitu:

\section{Diskriminasi Gender}

Diskriminasi adalah perlakuan yang tidak seimbang terhadap perorangan atau kelompok berdasarkan sesuatu yang bersifat kategorikal atau atribut-atribut khas seperti berdasarkan ras, kesukubangsaan, agama, atau keanggotaan kelas-kelas sosial (Theodorson \& Theodorson dalam Idi, 2018). Diskriminasi menjadi perilaku yang ditujukan untuk mencegah atau membatasi satu kelompok lain yang berusaha memiliki atau mendapatkan sumber daya dengan mengurangi, memusnahkan, menaklukkan atau mengasimilasi kelompok lain.

Tindakan diskriminasi dilakukan oleh kaum mayoritas dalam suatu kelompok besar yang mendominasi kelompok tersebut dan kaum minoritas lemah dalam kelompok tersebut. Bentuk tindakan diskriminasi dapat berupa ucapan secara lisan ( verbal ) maupun perilaku (nonverbal). Diskriminasi terjadi dalam proses interaksi atau komunikasi antar individu satu dengan individu lainnya, baik secara perorangan atau berkelompok dengan menindas salah satu pihak menggunakan ucapan dan perilaku yang menyinggung individu atau kelompok lain.

Diskriminasi awal mulanya muncul dikarenakan ada perbedaan antara manusia yang didasari pada ketidakpahaman dan ketidakpedulian terhadap kelompok lain.Perbedaan tersebut dipelajari dari pengaruh sosial orang lain dan dapat memicu adanya prasangka dan stigma. Diskriminasi muncul apabila prasangka dan stigma tersebut berubah menjadi aksi nyata atau tingkah laku seseorang yang buruk terhadap kelompok sosial tertentu (Fulthoni, dkk. 2009). Kelompok sosial terbentuk berdasarkan suku, ras, kasta sosial, penyakit, jenis kelamin, dan gender.

Gender merupakan kategori kelompok sosial yang terdiri atas perilaku yang dipelajari dengan melihat bagaimana budaya tertentu membedakan peran sosial feminin dan maskulin lalu membentuk kelompok menjadi maskulinitas dan femininitas. Diskriminasi berdasarkan gender dibagi menjadi lima yaitu marginalisasi, subordinasi, 
stereotip, kekerasan, dan beban kerja (Fakih, 2008).

Pertama, marginalisasi adalah proses peminggiran kelompok atau seseorang berdasarkan jenis kelamin yang dapat mengakibatkan kemiskinan dikarenakan beberapa faktor seperti kebijakan pemerintah, keyakinan tradisi, tradisi agama, kebiasaan, dan ilmu pengetahuan.

Kedua, subordinasi adalah suatu penilaian peran yang dilakukan oleh satu jenis kelamin lebih rendah dari jenis kelamin yang lain seperti menganggap perempuan lebih lemah dibandingkan dengan laki-laki.

Ketiga, stereotip atau pelabelan adalah pemberian nama atau istilah yang dilakukan dalam satu atau lebih hubungan kelompok yang digunakan untuk alasan membenarkan tindakan kelompok yang satu terhadap kelompok lainnya. Pelabelan ini sering menggunakan gender sebagai dasarnya seperti menganggap perempuan yang memiliki banyak teman laki-laki itu merupakan perempuan jalang.

Keempat, kekerasan adalah sebuah tindakan yang menyakiti orang lain baik secara fisik maupun non fisik. Kekerasan fisik dapat berupa pemukulan, pemerkosaan, perampokan, dan lain-lain.

Kelima, beban ganda adalah salah satu jenis kelamin memiliki lebih banyak pekerjaan dibandingkan jenis kelamin lainnya. Beban ganda menggunakan tugas atau tanggung jawab pekerjaan sebagai tolak ukurnya seperti pekerjaan rumah (membersihkan rumah, memasak), pekerjaan rumah (atasan dan bawahan).

\section{Teori Interaksi Simbolik}

Teori Interaksi Simbolik pada mulanya dicetuskan oleh George Herbert Mead yang menekankan bahwa pemikiran, konsep diri, dan komunitas manusia atau masyarakat tercipta dari proses komunikasi yang mana terdapat hubungan antara interaksi dan simbol. Walaupun Mead tidak pernah mempublikasikan gagasannya, muridnya yang bernama Herbert Blumer mengumpulkan catatan dan menciptakan istilah interaksionisme simbolik atau interaksi simbolik.

Ada tiga asumsi yang dikembangkan Blumer dalam teori ini (Griffin, 2012 : 55). Blumer memulai dengan asumsi yang pertama dengan menyatakan "manusia akan bertindak atau merespon interaksi dengan orangorang atau hal-hal berdasarkan dari makna yang mereka berikan atau sepakati kepada orang-orang atau hal-hal lain.”. Asumsi Blumer yang kedua menyatakan "makna tercipta dari interaksi sosial antara orangorang dengan menggunakan bahasa, maka dari itu makna tidak selalu melekat pada objeknya.". Asumsi ketiga Blumer menyatakan bahwa "interpretasi seseorang terhadap simbol dimodifikasi oleh proses pemikiran individu itu sendiri.". Ada pula tiga konsep penting dalam teori ini yaitu pemikiran (mind), diri (self), dan masyarakat (society) (West \& Turner, 2012). Mind atau pemikiran merupakan kemampuan menggunakan simbol-simbol dengan makna sosial yang sama dalam sebuah fase berpikir dan pengambilan peran. Self atau diri merupakan kemampuan merefleksikan bagaimana seseorang 
dilihat oleh orang lain. Society atau masyarakat merupakan jejaring hubungan sosial yang diciptakan dan direspon oleh manusia.

\section{Komunikasi Verbal Semantik}

Komunikasi digunakan oleh manusia untuk menyampaikan pemikiran, perasaan, pertukaran informasi dengan manusia lainnya. Komunikasi merupakan suatu pikiran, suatu makna, atau suatu pesan yang dianut secara bersamasama (Mulyana, 2008).

Komunikasi dapat dibedakan menjadi dua bentuk yaitu komunikasi verbal yang menggunakan kata-kata dalam sebuah percakapan secara lisan dan tertulis dan komunikasi nonverbal yang menggunakan bentuk tingkah laku, gestur, dan mimik wajah manusia secara spontan untuk berkomunikasi (Kusumawati, 2016). Proses komunikasi tersebut memerlukan bahasa sebagai mediator penyampaian pesan yang akan disampaikan kepada individu lainnya. Bahasa dapat dipahami apabila ada kesepakatan antara anggota kelompok untuk memaknai simbol tersebut.

Kata-kata sebagai simbol dalam bahasa dapat dirangkai menjadi sebuah kalimat yang dapat digunakan dalam proses komunikasi secara lisan maupun tertulis. Katakata tersebut memiliki berbagai macam makna dan apabila disusun berdasarkan peraturan tata bahasa maka kata-kata tersebut dapat membentuk sebuah kalimat yang memiliki makna baru mewakili pemikiran seseorang. Gabungan dari kata-kata tersebut merupakan semantik. Kiehl Lehrer yang merupakan professor filsafat dari Universitas Arizona berpendapat bahwa semantik merupakan studi tentang makna (Djajasudarma, 2009).

Berdasarkan penjelasan tersebut maka komunikasi verbal semantik adalah proses interaksi antar individu secara lisan dan tertulis dengan menyusun atau menggabungkan beberapa kata menjadi sebuah kalimat sesuai dengan peraturan tatabahasa. Katakata dalam bahasa memiliki sebuah makna dan secara teknis semantik mempelajari tentang makna bahasa tersebut.

Computer Mediated Communication (CMC)

Menurut Shedletsky dan Aitken (dalam Prasetyo dkk, 2018) Computer Mediated Communication $(C M C)$ adalah proses komunikasi antara manusia seperti menulis catatan, mengirim, menerima, dan membaca pesan dengan menggunakan komputer sebagai medianya. Pertukaran pesan dalam proses komunikasi disampaikan menggunakan perantara bentuk teknologi yang sederhana seperti kertas hingga teknologi yang canggih seperti komputer dan internet. Proses komunikasi yang dahulu dilakukan secara langsung atau tatap muka (immediate) saat ini mengalami perkembangan sehingga komunikasi dapat dilakukan tanpa memerlukan tatap muka atau secara tidak langsung.

Computer Mediated

Communication (CMC) menurut Newhage dan Rafaeli (dalam Prasetyo dkk, 2018 : 5) memiliki lima faktor penting yaitu switching, 
sensory appeal, interactivity, synchronicity, dan hypertextuality. Seiring berkembangnya teknologi, internet tidak hanya bisa mengakses informasi saja namun juga dapat digunakan untuk berkomunikasi antar individu lainnya secara lisan maupun tertulis. Seseorang bisa melakukan panggilan telepon dengan suara atau menulis surat elektronik. Selain internet, webcam atau kamera dalam komputer juga dapat digunakan untuk melakukan panggilan dengan menampilkan visual secara riil. Penggunaan internet dan webcam dipermudah dengan adanya software atau aplikasi untuk melakukan proses komunikasi menggunakan media komputer.

Teknologi komunikasi dalam perkembangannya tidak lagi hanya berupa komputer namun juga telepon genggam dan perangkat lainnya yang terhubung dengan internet. Penggabungan antara telepon genggam dan internet memunculkan media komunikasi baru yaitu smartphone. Smartphone memiliki kemampuan yang sama dengan komputer dan teknologi komunikasi ini semakin sering digunakan karena penggunaan yang mudah, ringan, dan cepat.

\section{Metode Penelitian}

Jenis penelitian yang digunakan dalam penelitian ini adalah kualitatif yang digunakan untuk memahami fenomena tentang apa yang dialami oleh subyek penelitian seperti perilaku, persepsi, motivasi, dan tindakan, dan lain-lain (Moleong, 2014).

Penelitian ini digunakan untuk memahami fenomena diskriminasi perempuan yang dialami oleh pemain perempuan saat bermain Mobile Legends: Bang Bang. Penelitian ini menggunakan metode fenomenologi yang merupakan pengalaman manusia mengenai sesuatu yang menekankan dualisme tubuh dan pikiran (Semiawan, 2010 : 81). Penelitian fenomenologi ini digunakan dengan menanyakan apa yang mereka alami dan bagaimana mereka memaknai pengalaman dan menafsirkan pengalaman tersebut.

Subyek dalam penelitian ini yaitu tujuh pemain perempuan. Sebelum memilih narasumber pemain perempuan sebagai subyek penelitian, Peneliti melakukan pra riset dengan observasi atau pengamatan kepada perempuan yang bermain game Mobile Legends: Bang Bang. Pemain yang dipilih merupakan pemain yang berusia diatas 20 tahun yang aktif bermain MLBB selama lebih dari 2 tahun dan bermain games dengan durasi lebih dari satu jam perhari karena pemain yang aktif memiliki banyak pengalaman saat bermain mobile games sehingga dapat memberikan data mengenai komunikasi yang terjalin selama bermain games. Selain memilih berdasarkan kriteria, ketujuh pemain perempuan dipilih yang berasal dari daerah yang berbeda-beda. Hal ini menjadi keistimewaan dari pemain perempuan yang pilih karena ada keberagaman pengalaman yang diperoleh pemain perempuan Mobile Legends: Bang Bang.

Penelitian ini menggunakan teknik pengumpulan data melalui wawancara dan Focus Group Discussion (FGD). Wawancara dipilih sebagai salah satu teknik pengumpulan data karena proses 
pencarian informasi dapat dilakukan secara mendalam dan personal kepada pemain perempuan mengenai diskriminasi yang pernah dialaminya. FGD dilakukan bersama pemain perempuan dengan mendiskusikan permasalahan mengenai diskriminasi pada pemain perempuan saat bermain Mobile Legends: Bang Bang. Wawancara dan Focus Group Discussion (FGD) dilakukan secara online menggunakan Zoom dan Google Meet karena pada saat penelitian ini berlangsung, wilayah Indonesia dan negara lainnya sedang dilanda pandemi virus Covid 19 yang mana seluruh manusia wajib melakukan social distancing demi mengurangi penularan wabah virus Covid 19.

\section{Hasil Penelitian dan} Pembahasan

Hasil wawancara dengan tiga pemain perempuan dan hasil Focus Group Discussion (FGD) yang berupa kesimpulan dari hasil diskusi bersama empat pemain perempuan merupakan temuan data yang digunakan untuk analisis penelitian mengenai diskriminasi pada pemain perempuan. Analisis menggunakan empat teori yang dipilih yaitu Teori Interaksi Simbolik, Komunikasi Verbal Semantik, Diskriminasi Gender, dan Computer Mediated Communication (CMC).

Analisis menggunakan teori dilakukan dengan menyesuaikan topik sehingga dalam satu topik analisis terdapat dua atau lebih teori yang digunakan. Tiga topik analisis penelitian ini yaitu proses komunikasi antar pemain Mobile Legends: Bang Bang, Identifikasi Pesan dari Makna Kata-kata dan
Kalimat Diskriminatif, dan Diskriminasi Perempuan dalam Game Mobile Legends: Bang Bang.

\section{Pemain Perempuan dan Identitas Virtual}

Saat membuat akun Mobile Legends: Bang Bang, pemain mengisi biodata yang berisi e-mail, ID name, foto profil, durasi online, pekerjaan, dan bio. Setiap pemain memiliki kebebasan dalam mengisi profil tersebut sehingga pemain bisa memilih menggunakan identitas yang asli atau identitas yang palsu. Berdasarkan hasil wawancara, kedua pemain perempuan yaitu Octa dan Dini menggunakan foto dan nama palsu pada akun Mobile Legends: Bang Bang mereka serta tidak menunjukkan identitas gendernya.

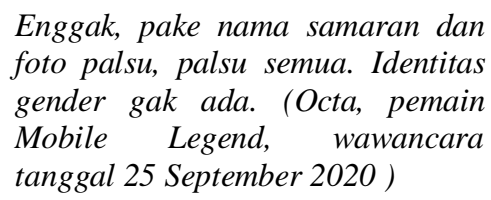

Pernyataan Dini dan Octa tersebut berbeda dengan Katya yang menggunakan foto asli dan nama palsu serta menyertakan identitas gendernya pada akun Mobile Legends: Bang Bang.

Fotonya foto asli, namanya enggak. Nah itu aku dulu itu gak pakai identitas gendernya tapi sekarang aku pakai female. (Katya, pemain Mobile Legend, wawancara tanggal 25 September 2020)

Kedua pemain perempuan yaitu Dini dan Octa malas bila identitas gendernya diketahui oleh pemain lain karena takut dihubungi secara personal oleh pemain lain dan 
mendapat perlakuan berbeda saat identitas gendernya diketahui.

Kalo dalam dunia game kan kita pake username game gitu kan, ciri khasnya gitu. Dulu pernah pake foto sendiri dan itu berakhir kayak orang-orang itu tau kamu siapa, sedangkan aku tidak ingin diketahui aku itu siapa. Soalnya kalo di mobile legends itu kerasa banget kalo ketahuan cewek gitu langsung orang-orang gak tau kenapa langsung lebih agresif, antusias gitu. Aku males gitu kalau orang tahu apalagi kalo performanya jelek jadi setelah itu aku gak pernah pake foto mukaku.(Dini, pemain Mobile Legend, wawancara tanggal 25 September 2020)

Pernyataan tersebut berbeda dengan Katya yang beranggapan bahwa apabila menggunakan foto asli, pemain lain tidak akan menduga bahwa foto tersebut asli melainkan palsu sehingga tidak masalah apabila menggunakan foto asli. Namun demikian, ID name tetap menggunakan nama palsu karena takut namanya dicari oleh pemain lain di media sosial.

Fotoku asli karena biasanya kalo kita pakai foto cewek itu kita gak dikira cewek. Karena kalau kadang itu cowok-cowok pasti yang di mobile game main tapi pakai fotofoto cewek gitu, entah foto pacarnya atau foto cewek random itu sering banget. Terkadang setelah aku pakai foto cewek, aku pasti dikira cowok gitu lho. (Wawancara dengan Katya, tanggal 25 September 2020 )

Menurut Katya, banyak pemain laki-laki yang menggunakan foto perempuan (foto pacarnya atau foto perempuan lain) sebagai foto profilnya dan banyak yang mengira orang-orang dengan foto perempuan merupakan pemain laki-laki sehingga ada pemain lain yang mengajak bermain bersama lagi atau dengan istilah mabar.

Proses Komunikasi Antarpemain di Mobile Legends: Bang Bang

Proses komunikasi yang terjalin di antara pemain saat bermain game Mobile Legends: Bang Bang. Game tersebut menghadirkan sebuah fitur di mana para pemain dapat melakukan komunikasi secara langsung tanpa bertatap muka yaitu dengan menggunakan fitur chat dan voice chat yang terdapat pada tampilan layar saat bermain game.

Proses komunikasi antar manusia dapat dilakukan dengan menggunakan komputer dan internet, sama seperti proses komunikasi yang terjalin di antara pemain saat bermain game Mobile Legends: Bang Bang. Game tersebut menghadirkan sebuah fitur di mana para pemain dapat melakukan komunikasi secara langsung tanpa bertatap muka. Komunikasi dilakukan dengan menggunakan fitur chat dan voice chat yang terdapat pada tampilan layar saat bermain game. Fitur chat dan voice chat tersebut memiliki lima faktor penting yang sesuai dengan konsep Computer Mediated Communication (CMC) menurut Newhage dan Rafaeli dalam journal of CMC 1996 (Prasetyo dkk, 2018 : 5): (1). Switching, yaitu bentuk-bentuk komunikasi seperti teks dan audio dapat dikirim dan diterima oleh pemain lain dalam Mobile Legends: Bang Bang dengan mudah melalui fitur chat dan voice chat yang tersedia serta sambungan jaringan 
internet. (2) Sensory appeal, yaitu komunikasi yang melibatkan panca indera dan perasaan manusia dapat tersalurkan dengan baik menggunakan fitur chat dan voice chat dalam Mobile Legends: Bang Bang. (3) Interactivity, yaitu Smartphone sebagai media untuk bermain Mobile Legends: Bang Bang dapat menjadi alat komunikasi yang reflektif dan responsive. (4). Synchronicity, yaitu komunikasi yang menggunakan komputer yang dalam hal ini berbentuk smartphone lebih fleksibel karena proses komunikasi yang bersifat cepat melibatkan individu-individu agar umpan balik pesan dapat langsung diperoleh. (5) Hypertextuality, yaitu komunikasi dengan media komputer (smartphone) merupakan komunikasi yang berbentuk non linear yaitu komunikasi dua arah antara komunikan (pemberi informasi dan penerima informasi) yang mana terdapat umpan balik antara komunikan berupa tanya jawab dan sanggahan.

Temuan data mengenai komunikasi antar pemain juga sesuai dengan asumsi pertama dalam Teori Interaksi Simbolik mengenai manusia yang bertindak atau merespon interaksi dengan orangorang berdasarkan dari makna yang mereka berikan atau sepakati. Saat mendapat kalimat atau perkataan yang kurang menyenangkan dari pemain lain, pemain perempuan memilih membalas perkataan tersebut dengan kata-kata dan kalimat yang kurang menyenangkan juga.

Berdasarkan hasil wawancara, Informan mengatakan bahwa Informan tidak mau diejek dan dimaki saat dia tidak salah sehingga Informan akan membalasnya dan pada saat diejek mereka merasa emosi serta kesal sehingga membalas ejekan tersebut. Berdasarkan pengalaman keempat pemain perempuan peserta FGD, para Informan mengatakan akan melihat kondisi terlebih dahulu. Apabila mereka bermain dengan buruk maka mereka sadar diri dan memilih diam serta membiarkan saja, namun saat mereka bermain dengan baik lalu mendapat ejekan maka mereka membalas ejekan tersebut.

\section{Identifikasi Pesan dari Makna Kata-kata dan Kalimat Disk riminatif}

Berdasarkan data dari hasil wawancara, kata-kata seperti Bangsat, Jancuk, Goblok, Tolol, Jelek, dan Stupid sering digunakan untuk mengumpat sesuatu. Berbeda dengan kata Anjing, Babi, Dog, dan Pig yang berubah pemaknaanya menjadi negatif karena sering digunakan untuk mengumpat. Hal tersebut sesuai dengan asumsi kedua dalam Teori Interaksi Simbolik yang membahas tentang makna yang tercipta tidak selalu melekat pada objeknya. Berdasarkan hasil interaksi sosial, makna dari kata-kata tersebut sebagian besar tidak melekat pada objeknya.

Kata-kata tersebut berbeda dengan kata Beban yang digunakan untuk mengejek pemain bukan untuk mengumpat pemain. Kata Beban dalam komunikasi antarpemain memiliki makna bahwa pemain menjadi sesuatu yang berat yang menghambat tim saat bermain game. Kata-kata lainnya seperti kata Anak Haram memiliki makna yang 
menghina seseorang karena menganggap orang tersebut sebagai anak yang sangat berdosa. Kata-kata di atas digunakan untuk mengumpat seseorang tanpa menyinggung gender perempuan ataupun laki-laki dan digunakan sebagai pelampiasan emosi serta kemarahan seseorang.

Ada pula kata-kata lainnya yang mengarah pada diskriminasi karena menindas salah satu pihak menggunakan ucapan yang menyinggung individu atau kelompok lain. Berdasarkan data, pemain lain menindas perempuan menggunakan ucapan yang menyinggung perempuan yaitu menggunakan kata Pelacur, Lonte, dan Pecun. Pemain lain menindas pemain perempuan dan menyebut pemain perempuan sebagai sosok yang liar, nakal dan perempuan yang melanggar norma dalam kehidupan masyarakat.

Selainkata-kata diskriminatif, Peneliti mengumpulkan kalimat diskriminatif. Kalimat diskriminatif berasal dari penggabungan beberapa kata atau semantik yang memiliki makna negatif. Ada kalimat yang digunakan untuk mengejek pemain lain. Semantik yang terdapat dalam kalimat-kalimat tersebut memiliki makna yang menyinggung seseorang dari segi kemampuan, fisik, dan kelompok pemain. Ada kalimat yang digunakan untuk mengungkapkan rasa kesal, marah, dan emosi kepada pemain lain. Pada setiap kalimat terdapat kata-kata umpatan yang digunakan sebagai luapan emosi pemain. Ada kalimat yang menyinggung perempuan karena secara langsung ditujukan kepada perempuan. Kalimat-kalimat tersebut juga merendahkan perempuan karena semantik dalam kalimat memiliki makna bahwa perempuan tidak selayaknya bermain game karena memiliki kemampuan yang lebih rendah dibandingkan dengan lakilaki. Selain itu, ada penggunaan kata Pelacur dan Lonte yang menyudutkan perempuan seperti penjelasan pada bagian kata-kata diskriminatif.

\section{Diskriminasi Perempuan dalam Game Mobile Legends: Bang Bang}

Pemain perempuan mendapat perlakukan yang tidak seimbang dari pemain lain berdasarkan gender mereka yang mengarah ke diskriminasi. Bentuk perlakuan diskriminasi tersebut berupa lontaran kalimat secara tertulis di fitur chat dan lisan melalui fitur voice chat yang menyinggung pemain perempuan.

Kata makian dan umpatan biasanya menggunakan kata seperti anjing, bangsat, dan jancuk. Namun ada pula umpatan lain dengan kata Alat kelamin organ vital laki-laki serta organ vital perempuan. Berdasarkan hasil FGD dan wawancara, pemain perempuan Santika pernah mendapat kata umpatan seperti kata anjing, tolol, dan noob. Kata "noob" dapat diartikan sebagai pemain baru yang belum memiliki skill bermain yang bagus. Kata tersebut sering digunakan untuk mengejek pemain lain saat mereka bermain dengan buruk. Katya pernah mendapat ejekan karena pemain lain menganggap Katya sebagai beban di tim terlebih pada saat memiliki peran yang penting dalam tim, begitu juga dengan Dini.Selain menggunakan kata-kata umpatan, pemain lain juga 
mengejek menggunakan hero apabila mereka berperan selama permainan dengan buruk. Peran atau role menggunakan hero dalam permainan sangat penting bagi pemain karena mempengaruhi hasil pertandingan. Apabila peran yang dimainkan kurang baik maka bisa memicu perselisihan antar pemain. Rifa pernah diejek dengan menggunakan nama hero yang digunakan beserta umpatan "babi". Perbedaan hero berdasarkan gender ternyata turut memicu pemain lain untuk mengutarakan ejekan kepada pemain yang menggunakan hero tersebut. Pengelompokan hero tidak hanya berdasarkan kekuatannya saja namun dapat berdasarkan gender yaitu lakilaki dan perempuan. Pengelompokan tersebut bisa dilihat dari tampilan hero yang menyerupai laki-laki serta perempuan.

Umpatan dan kalimat ejekan dengan perkataan yang merendahkan perempuan juga pernah dialami oleh pemain perempuan. Apabila identitas gender mereka diketahui oleh pemain lain maka pemain lain mengejek langsung menunjuk ke identitas gendernya.

Perempuan yang bermain game masih dianggap sebelah mata oleh pemain lain. Dalam kehidupan sosial manusia, perempuan lebih sering berada di dapur dan mengurusi rumah tangga.

Kata ejekan tersebut ternyata tidak diutarakan untuk pemain perempuan saja tetapi juga mengejek orang tua (bapak dan ibu) dari pemain. Selain Dini, Lian juga mengalami hal yang sama yaitu diejek membawa orang tua dengan menggunakan kata-kata "kelamin". Lian berpendapat bahwa ejekan membawa orang tua sebenarnya tidak tepat karena game tidak ada hubungannya dengan orang tua.

Saat mendapat kalimat atau perkataan yang kurang menyenangkan, pemain perempuan membalas perkataan tersebut dengan mengejek dan juga memaki pemain yang mengejeknya. Dini membalas perkataan tersebut karena Dini tidak salah dalam bermain game sehingga Dini tidak terima jika diejek. Begitu juga dengan Katya dan Octa yang membalas perkataan kurang menyenangkan tersebut ke pemain yang mengejeknya dengan kalimat ejekan dan umpatan.

Pemain perempuan tidak selalu membalas ejekan ke pemain lain. Lian, Ari, Rifa, dan Santika melihat kondisi dan merefleksikan performa mereka saat bermain game. Jika mereka bermain dengan baik dan mendapat ejekan dari pemain lain, maka mereka membalas ejekan tersebut. Namun jika mereka merasa bermain kurang baik dan mendapat ejekan dari pemain lain, mereka diam saja dan tidak membalas ejekan tersebut.

Kemudahan berkomunikasi memberikan ruang yang luas bagi seseorang untuk menyampaikan pesannya. Dalam hal ini, CMC memiliki peran yang besar dalam berkembangnya proses komunikasi dalam dunia game khususnya Mobile Legends: Bang Bang. Walaupun demikian, proses komunikasi dengan pesan yang tidak sesuai dapat memicu adanya penindasan atau diskriminasi bagi sekelompok orang.

Pemain perempuan mendapat perlakukan yang tidak seimbang dari pemain lain berdasarkan gender mereka yang mengarah ke 
diskriminasi. Bentuk perlakuan diskriminasi tersebut berupa lontaran kalimat secara tertulis di fitur chat dan lisan melalui fitur voice chat yang menyinggung pemain perempuan. Berdasarkan temuan data dan analisis, Peneliti mengumpulkan simbol diskriminasi perempuan menjadi satu dalam sebuah tabel. Berikut tabel simbol diskriminasi perempuan berupa katakata dan kalimat yang diperoleh dari hasil analisis pengalaman pemain perempuan saat mereka berkomunikasi dengan pemain lain dan bermain Mobile Legends: Bang Bang.

Tindakan diskriminasi tersebut terkadang mempengaruhi kondisi diri dalam kehidupan sehari-hari. Berdasarkan hasil wawancara dengan Katya, Katya berpendapat bahwa terkadang merasa sungkan untuk bermain game saat berada di tempat umum terlebih saat bermain dengan laki-laki. Pendapat tersebut sedikit berbeda dengan pendapat Dini yang mengatakan bahwa tidak terlalu mempengaruhi kesehariannya namun merasa kecil hati karena takut dimaki dan diejek oleh orang lain. Berbeda dengan Octa yang tidak begitu terpengaruh dengan kondisi kesehariannya apabila sebelumnya mengalami diskriminasi saat bermain game.

Pemain perempuan berpendapat bahwa diskriminasi dalam dunia game tidak sepatutnya ada karena game diciptakan untuk semua orang tanpa memandang identitas gender mereka. Octa berpendapat bahwa tidak semua game seperti pertarungan identik dengan laki-laki saja. Game tersebut bisa dimainkan juga oleh perempuan. Begitu juga dengan Dini yang berpendapat bahwa stereotype tentang game untuk laki-laki harus dihilangkan agar diskriminasi gender dalam dunia game juga menghilang.

Semua pemain baik laki-laki dan perempuan diharapkan memiliki kesadaran mengenai diskriminasi dalam dunia game agar para pemain game khususnya Mobile Legends: Bang Bang bisa menghindari serta menghilangkan diskriminasi saat bermain game.

Diskriminasi yang dialami oleh pemain perempuan ini mengarah ke diskriminasi subordinasi karena adanya penilaian peran bahwa perempuan lebih lemah bermain game dibandingkan dengan laki-laki. Perbedaan kekuatan antara laki-laki dan perempuan menjadi pemicu stigma bahwa perempuan merupakan manusia yang lemah. Diskriminasi kepada pemain perempuan muncul karena pemain lain mungkin tidak memahami alasan mengapa perempuan bermain Mobile Legends: Bang Bang. Selain itu, peran sosial perempuan dalam keluarga yang selalu berada di dapur dan mengurus rumah tangga menciptakan pelabelan atau stereotip bahwa perempuan identik dengan kegiatan di dapur.

Pelabelan ini memberikan pemahaman khususnya bagi pemain bahwa perempuan biasanya melakukan kegiatan sehari-hari di dapur untuk memasak dan tidak melakukan aktivitas bermain game. Akibat pemahaman tersebut, pemain yang mengetahui adanya perempuan yang bermain game memberlakukan pemain perempuan berbeda dengan pemain lain. 


\begin{abstract}
Diskriminasi terjadi pada berbagai dimensi, bahkan pada sektor hiburanpun, diskriminasi gender masih saja terjadi. Melalui hasil wawancara, dapat terlihat bahwa bentuk diskriminasi yang ditujukan kepada perempuan meliputi kata-kata umpatan dengan merujuk pada peminggiran perempuan di lingkungan sosial (seperti kata pelacur), menyamakan perempuan dengan binatan (anjing dan babi), dan meminggirkan perempuan dari segi intelektualitas (bodoh, tolol). Pada online games seperti Mobile Legend yang keunggulan pemain seharusnya ditunjukkan melalui kemampuannya berstrategi dan ketangkasan bermain, dilabeli sebagai 'area maskulin' .

Hasil penelitian ini menunjukkan bahwa kesetaraan haruslah holistik karena fenomena diskriminasi tidak berhenti pada sebagian sektor kehidupan seperti pekerjaan, sosial, dan pendidikan tetapi juga pada berbagai aspek yang seharusnya netral seperti permainan.
\end{abstract}

\section{Simpulan}

Penelitian ini menunjukkan bahwa dalam kegiatan hiburan seperti bermain permainan interaktif, diskriminasi gender masih terjadi. Hal ini ditunjukkan melalui umpatan yang diucapkan maupun dituliskan dalam bentuk live chat. Pemain perempuan menjadi sasaran diskriminasi verbal, melalui stereotipe dan pelabelan yang diberikan oleh para pemain. Hal ini membuat pemain perempuan berstrategi untuk menghadapi situasi dan tetap terlibat dalam permainan.
Melalui penelitian ini, maka perlu adanya pemahaman mengenai kesetaraan yang holistik dan tidak terbatas pada aspek-aspek pekerjaan dan budaya saja.

\section{Daftar Pustaka}

Abriani A. I., Abdullah Z., Sumule M. (2018). Perilaku Komunikasi Pengguna Game Online: "Mobile Legends". Jurnal Ilmu Komunikasi UHO, 8(2).

Denny J.A. (2014). Menjadi Indonesia Tanpa Diskriminasi: Data, Teori, dan Solusi. Jakarta: Inspirasi.co.

Djajasudarma, T. F. (2009). Makna Leksikal dan Gramatikal. Bandung: Refika Aditama.

Fulthoni, Arianingtyas, R., Aminah, S., Sihombing, U.P. (2009). Buku Saku untuk Kebebasan Beragama: Memahami Diskriminasi. Jakarta: The Indonesian Legal Resource Center (ILRC).

Griffin, E. M.. (2012). A First Look at Communication Theory. New York: McGraw-Hill.

Idi, A. (2018). Konflik Etno-Religius di Asia Tenggara. Yogyakarta: LKiS.

Kemp, S. (2020). Digital 2020: Global Digital. Retrieved 2 December 2020. from https://datareportal.com/repo rts/digital-2020-globaldigitaloverview? format $=a m p$

Kusumawati, T. I. (2016). Komunikasi Verbal dan Nonverbal. Jurnal Pendidikan dan Konseling, 6(2), 83-98. 
Maulida, L. (2018). Jumlah Gamer di Indonesia Capai 100 Juta di 2020. Retrieved 1 April 2020, from https://www.tek.id/insight/ju mlah-gamer-di-indonesiacapai-100-juta-di-2020b1U7V9c4A/

Moleong, L. (2014). Metode Penelitian Kualitatif. Bandung: PT Remaja Rosdakarya.

Mulyana, D. (2008). Ilmu Komunikasi: Suatu Pengantar. Bandung: Remaja Rosdakarya.

Murnalungito, D. N. (2016). Diskriminasi Gender terhadap Peserta Didik Perempuan yang Hamil Peserta di Jenjang Pendidikan Sekolah Menengah Atas. Skripsi. Fakultas Hukum, Universitas Atma Jaya Yogyakarta.

Prasetyo, B. D., dkk. (2018). Komunikasi Pemasaran Terpadu (Pendekatan Tradisional hingga Era Media Baru). Malang: UB Press.

Saputra, I. A. (2019). Pengakuan Tim eSports Cewek FF Gaming Hadapi Pelecehan saat Main Game. Retrieved 10 March 2020, from https://kumparan.com/kumpa rantech/pengakuan-timesports-cewek-ff-gaminghadapi-pelecehan-saat-maingame-1548481725159498958

Semiawan, C. R. (2010). Metode Penelitian Kualitatif: Jenis,
Karakteristik dan Keunggulannya. Jakarta: Grasindo.

Tahar, F. (2012). Pengaruh Diskriminasi Gender dan Pengalaman terhadap Profesionalitas Auditor. Skripsi. Fakultas Ekonomi, Universitas Hasanuddin Makassar

Ulum, B. (2018). Game "Mobile Legends: Bang Bang” di Kalangan Mahasiswa UIN Sunan Ampel Surabaya dalam Tinjauan "One Dimensional Man” Herbert Marcuse. Skripsi. Fakultas Ushuluddin dan Filsafat, Universitas Islam Negeri Sunan Ampel Surabaya.

Usmanda, Y. 2019. Perilaku Toxic, Tantangan Berat Gamer di Media Sosial. Retrieved 31 August 2020, from https://www.kincir.com/game /mobile-game/perilaku-toxictantangan-besar-gamer-dimedia-sosial

West, R. \& Turner, H.L.. (2012). Introduction communication theory: analysis and application. New York : McGraw-Hill.

Yogatama, I. K. S., Agi P. K., Lutfi F. (2019). Analisis FaktorFaktor Yang Memengarruhi Minat Pemain Dalam Permainan MOBA (Studi Kasus Mobile Legends: Bang Bang!). Jurnal Pengemabngan Teknologi Informasi dan Ilmu Komputer, 3(3), 2558-2566 